\title{
Potency of Cell Wall Protein of Pasteurella multocida as Hemorrhagic Septicemia Vaccine on Swamp Buffaloes
}

\author{
HERLIANI $^{1}$, ABRANI SULAIMAN ${ }^{1}$, AND M. ILMI HIDAYAT ${ }^{2}$ \\ ${ }^{1)}$ Department of Animal Science, Fac. of Agriculture ULM, Jl. Jenderal Ahmad Yani Km. 36 \\ Banjarbaru (70714) \\ ${ }^{2)}$ Department of Agribussines, Fac. of Agriculture Uniska, Jl. Adhiyaksa No. 2, Kayu Tangi, Sungai \\ Miai, Banjarmasin Utara, Banjarmasin (70123)
}

\begin{abstract}
Vaccine testing of cell wall protein (Pasteurella multocida) aims to control hemorrhagic septicemia in (swamp buffalo) carried out at the Microbiology Laboratory of the Faculty of Agriculture, Lambung Mangkurat University, and Laboratory of Molecular Genetics, Faculty of Saint, Airlangga University. For field testing, it was carried out in Tampakang Village, Hulu Sungai Utara Regency and Banua Raya Village, Bati-Bati, Tanah Laut Regency. Safety tests using experimental animals (mice and swamp buffalo). The serum obtained was tested serologically using Enzyme-Linked Immunosorbent Assay (ELISA). 100\% vaccine safety test for mice and buffalo live without clinical symptoms as the characteristics of animals affected by hemorrhagic septicemia. With the ELISA method, the result of vaccinated swamp buffalo is positive antibody formation by seeing the increasing Optical Density (OD) value $\chi 450 \lambda \mathrm{m}$, before the vaccine 0.292 after vaccination 0.748 and 1.576 and 1.821 after the booster. Based on observations in the laboratory and in the field, both safety tests and potential test cell wall protein vaccines Pasteurella multocida of local isolates can be used to prevent hemorrhagic septicemia that attacks swamp buffalo, both laboratory and field scale.Keywords: Vaccine candidate, Pasteurella multocida, safety test, ELISA test.
\end{abstract}

Key words: Vaccine candidate, Pasteurella multocida, safety test, ELISA test

\section{INTRODUCTION}

Constraints faced by buffaloes in South Kalimantan vary, such as reduced grazing land which results in a reduced availability of natural food which causes buffalo body defenses to be reduced so that it is susceptible to disease, one of these diseases is Pasteurellosis caused by the bacterium Pasteurella multocida (P. multocida) and its variants. This bacterium can cause serious illness; this organism can infect many wild and domestic animal species, and can cause acute or chronic diseases (Alwis, 1992) in Herliani and Sulaiman (2011).

Pasteurella multocida is the main causative agent of SE disease in buffalo, pigs, goats,

Correspondence Author: Herliani. Department of Animal Science, Fac. of Agriculture, Lambung Mangkurat University, Jl. Jenderal Ahmad Yani Km. 36 Banjarbaru (70714), Indonesia, Email: herliani@ulm.ac.id deer and camels caused by serogroups Pasteurella multocida A, B and E; Fowl Cholera (FC) in poultry caused by Pasteurella multocida sero-group A (Eriksen et al. 1999; Wilkie et al., 2012), in addition Pasteurella multocida is also a major contributor to several respiratory disorders of Bovine Respiratory Disease Complex (BRDC) in cattle, and pneumonia in pigs and sheep (Gyles et al., 2011).

One effort to control bacterial infection Pasteurella multocida is through prevention efforts using vaccines. Various vaccines have been tried with varying degrees of protection (Carter et al., 1991 and Mosier, 1993 in Herliani and Sulaiman, 2011). In Indonesia, vaccine killed broth Bactria put into use from 1910-1970 (Syamsudin, 1993). There are currently several types of anti-vaccines Pasteurella multocida on the market, but the ability to protect is limited to only a few weeks (Supar and Tati Ariyanti, 2007). P. multocida

Journal of Wetlands Environmental Management 
is a pathogenthat still needs a lot of study. This is caused by the variety of diseases caused, as well as the number of host species affected, and the way the infection is not yet understood (Wilkie et al., 2012).

Recently, research on P. multocida has been widely reported, for example regarding virulence genes, and the nature of $P$. multocida as commensal, opportunistic, primary pathogens and metabolites as determinants of pathogenicity to the host (Gyles et al., 2011). $P$. multocida as a commensal bacterium can survive for a long time and reproduce without causing infection in the host (Diallo and Frost 2000). However, Pasteurella multocida commensal can also infect a host when the host is under stress, changes in the expression patterns of virulence factors in Pasteurella multocida, and a decrease in host immunity due to other microbial infections (bacteria, viruses or parasites). As a result Pasteurella multocida is able to reproduce rapidly in the upper respiratory tract and cause Bovine Respiratory Disease Complex (BRDC), despite the strong suspicion that Mannheim hemolytic as a predominant pathogen to BRDC (Griffin I. 2010; Kubatzky 2012).

Research into vaccine development beginning in the 1990s showed that the vaccine $P$. multocida local isolate provided better protection against homologous and heterologous strain testing in cattle and buffaloes (Ramdani, 1997). Similar results can be seen that the inactivated vaccine $P$. multocida local isolate from ducks can provide better protection compared to imported strains against homologous and heterologous strains in experimental ducks (Supar et al., 2001a, b; Herliani and Sulaiman, 2010).

Vaccination using live vaccines from the bacterium Pasteurella multocida apparently can increase the immune response that is high enough to somatic antigens and can increase resistance to infection given challenge. Vaccines are administered by aerosol, subcutaneous and intradermal (Mosier, 1993). Infected animals or infected animals are the main sources of infection for nearby animals. In addition, pasteurellosis can be contracted from latent infections in stressed animals. Stress factors other than due to weather changes and mismanagement are also often closely related to stress due to long-distance travel from the area of origin of livestock to abattoirs. (Crater and Alwis 1989; Alwis, 1981; Alwis and Vipulasiri, 1980).

Research on vaccines has been carried out, but no vaccine has been used for a long time. this might be due to the vaccine being used that is not protective, due to differences in antigenic properties between the isolates used with isolates in the field (which infect livestock) in accordance with the statement (Syamsuddin 1977 and Sommerset, et.al., 2005) the ideal vaccine must meet several requirements that are determined including immunogenic and protective, safe, stable and effective and efficient.

In South Kalimantan the vaccination was carried out with an inactivated $P$. multocida Katha strain from Myanmar. This vaccine is widely available in the market, but there are many variations in quality, efficacy or efficacy, and the composition of the vaccine used. Inactivated vaccines with oil adjuvants are very concentrated, making it difficult to apply, other than that the storage time is relatively short because they are easily damaged at room temperature, and often cause adverse local reactions.

\section{METHODOLOGY}

The isolate bacteria that founded in prior experiment in 2015 was used in this experiment. The bacteria was stored in the microbial laboratory of the Agriculture Faculty ULM, before it was cultured in BHI agar media. The bacteria isolate was identified based on phenotype character ie morphology, biochemistry, and physiology. Morphological observation refer to Cappucino and Sherman (2001). 


\section{Preparation of Cell Wall Protein}

Preparation of Pasteurella multocida cellwall protein was based De Boer dan Schaad method (1990).

\section{Safety Test of HS Vaccine}

Eight mices were vaccinated by intraperitoneal with $0.5 \mathrm{ml}$ vaccine per mouse. Other 4 mices were not vaccinated as control, and then all mouses were observed for 7 days. Two buffaloes about 4-5 months of age with body weight around $30 \mathrm{kgs}$ were inoculated by intramuscular (IM) vaccine with minimal dose $4 \mathrm{ml}$ and the observed for 21 days. Another buffalo was not vaccinated as the control also observed for 21 days. The vaccine is accomplished the standar if the vaccinated mices and the vaccinated buffaloes, also the controls are not shown clininical dissease symptoms.

\section{Potency Test of Vaccine}

Two buffaloes about 4-5 months of age with body weight around $30 \mathrm{kgs}$ were inoculated by intramuscular (IM) with vaccine that made in $1^{\text {st }}$ year experiemet with minimal dose $4 \mathrm{ml}$ (BW up to $40 \mathrm{~kg}=4 \mathrm{ml}$ ) and the observed for 14 days. After 14 days, the buffaloes were given boostering vaccination

\section{Measuring of Antibody Titres}

Measuring of antibody of blood serum samples was conducted by Enzyme -Linked immune Sorbent Assay (ELISA) method that develoved by Biology Department of UNAIR.

\section{RESULTS AND DISCUSSION}

Result of staining Pasteurella multocida bacteria from SE infected buffaloes seen on Figure 1. Identification of biochemistry refers to Cappucino dan Sherman (2001). Results of bacteria test were seen on Table 1. Based on the test, it can be concluded that sample bacteria was stored in the microbial laboratory of the Agriculture Faculty ULM and tested its pathogenesis on Balb $\mathrm{C}$ mice was Pasteurella multocida bacteria, this finding confirms to statement of De Alwis (1992) end Woolcock (1992), that Pasteurella multocida is bacteria with shorth stick form, size $1-2 \mu \mathrm{m}$ X $0.3-$ $1.0 \mu \mathrm{m}$, and gram-negative.

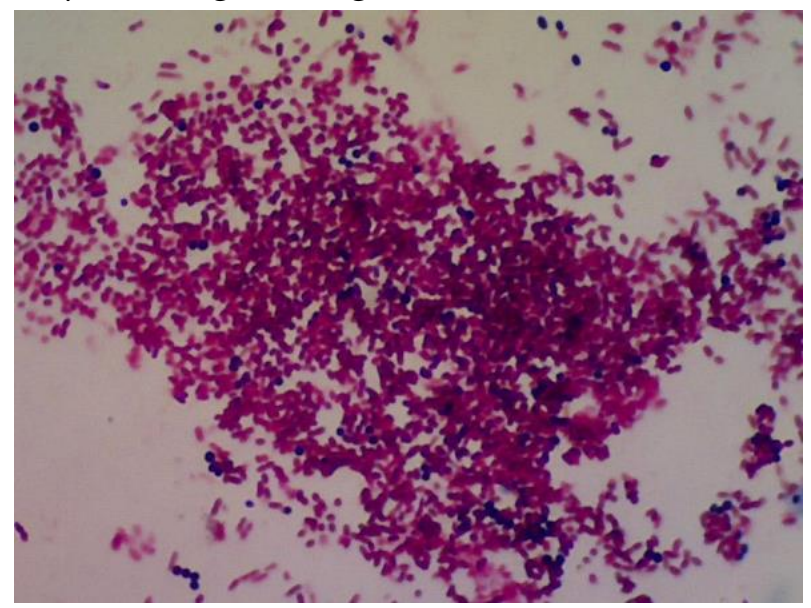

Figure 1. Gram staining of P. multocida bacteria in those isolated from lung organs 100x enlargement. 
Table 1. The results of testing the biochemical and physical properties of Pasteurella multocida bacteria

\begin{tabular}{|c|c|c|c|c|}
\hline \multirow[t]{2}{*}{ Characterization } & \multicolumn{3}{|c|}{ Results } & \multirow[t]{2}{*}{ Information } \\
\hline & Plate 1 & Plate 2 & Plate 3 & \\
\hline Gram & Negative & Negative & Negative & The bacteria looks red \\
\hline Form & Coccobacillus & Coccobacillus & Coccobacillus & $\begin{array}{l}\text { Bacteria are small rods and } \\
\text { both ends are rounded }\end{array}$ \\
\hline Spores & Negative & Negative & Negative & $\begin{array}{l}\text { Under a microscope, bacteria } \\
\text { appear to be entirely blue }\end{array}$ \\
\hline $\begin{array}{l}\text { Media Mac } \\
\text { Conkey }\end{array}$ & Grow & Grow & Grow & $\begin{array}{l}\text { The bacteria form small, } \\
\text { round, and serrated colonies }\end{array}$ \\
\hline Hemolysis & Negative & Negative & Negative & $\begin{array}{l}\text { In blood agar media, faded red } \\
\text { does not occur }\end{array}$ \\
\hline Motility & Negative & Negative & Negative & $\begin{array}{l}\text { Bacteria only grow on } \\
\text { puncture marks }\end{array}$ \\
\hline $\mathrm{O} / \mathrm{F}$ & Positive & Positive & Positive & $\begin{array}{l}\text { Change media color from } \\
\text { green to yellow }\end{array}$ \\
\hline Glucose & Positive & Positive & Positive & $\begin{array}{l}\text { Change media color from red } \\
\text { to yellow }\end{array}$ \\
\hline Lactose & Positive & Positive & Positive & $\begin{array}{l}\text { Change media color from red } \\
\text { to yellow }\end{array}$ \\
\hline Monnitol & Positive & Positive & Positive & $\begin{array}{l}\text { Change media color from red } \\
\text { to yellow (longer time) }\end{array}$ \\
\hline Indole & Positive & Positive & Positive & Red ring is formed \\
\hline Urease & Negtive & Negative & Negative & Not change media color \\
\hline Oxidase & Positive & Positive & Positive & $\begin{array}{l}\text { the color on the oxidation } \\
\text { stick turns blue }\end{array}$ \\
\hline Catalase & Positive & Positive & Positive & $\begin{array}{l}\text { Seen bubbles on the media } \\
\text { after adding } \mathrm{H}_{2} \mathrm{O}_{2} \text { solution }\end{array}$ \\
\hline
\end{tabular}

By giemsa staining of blood couting glass, the bacteria was seen bipolar, capsuled, and not motile. The bacteria have characteristic anaerobic facultative, easy grow on simple (basal) media, but it will grow rapidly with riched media by serum or blood. Growing colony in media agar inhibited hemolysis of red blood, the colony have characteristic round with plate periphery, concave elevancy, greyish color, diameter 1-3 mm and with specific odor.

\section{Result of Safety Test}

For safety testing, the results show that during experiment all mices and buffaloes still life without any clinical symptoms such as rainy noses, red eyes, swollen neck area, apathetic body, or increasing temperature, it is simmilar to report by Priadi dan Natalia (2002). The body temperature observed during experiment was around $38^{0-} 39^{\circ} \mathrm{C}$. This indicate that the vaccine is safe to use in treated animals, with dose 10 ul for mices and $4 \mathrm{ml}$ for buffalo, the results can be seen on Table 2 and Table 3. 
Table 2. The data of safety test on balb $\mathrm{C}$ mice.

\begin{tabular}{|c|c|c|c|c|c|c|c|c|c|}
\hline \multirow[t]{2}{*}{ Treatments } & \multirow[t]{2}{*}{ No } & \multirow{2}{*}{$\begin{array}{c}\text { Clinical } \\
\text { Symptoms }\end{array}$} & \multicolumn{7}{|c|}{ Dead Mice } \\
\hline & & & 1 & 2 & 3 & 4 & 5 & 6 & 7 \\
\hline \multirow{4}{*}{ Control Mice } & 1 & - & - & - & - & - & - & - & - \\
\hline & 2 & - & - & - & - & - & - & - & - \\
\hline & 3 & - & - & - & - & - & - & - & - \\
\hline & 4 & - & - & - & - & - & - & - & - \\
\hline \multirow{8}{*}{ Vaccinated Mice } & 1 & - & - & - & - & - & - & - & - \\
\hline & 2 & - & - & - & - & - & - & - & - \\
\hline & 3 & - & - & - & - & - & - & - & - \\
\hline & 4 & - & - & - & - & - & - & - & - \\
\hline & 5 & - & - & - & - & - & - & - & - \\
\hline & 6 & - & - & - & - & - & - & - & - \\
\hline & 7 & - & - & - & - & - & - & - & - \\
\hline & 8 & - & - & - & - & - & - & - & - \\
\hline Results & & \multicolumn{8}{|c|}{$\begin{array}{l}\text { All }(100 \%) \text { treated animals (Balb mice c) live and have no } \\
\text { symptoms of hemorrhagic septicemia }\end{array}$} \\
\hline Result Value & & \multicolumn{8}{|c|}{ Vaccines are safe to use } \\
\hline
\end{tabular}

Table 3. The Data Security Test on Swamp Buffaloes.

\begin{tabular}{|c|c|c|c|c|c|c|c|c|c|c|c|c|c|c|c|c|c|c|c|c|c|c|}
\hline \multirow{2}{*}{ Buffalo } & \multirow{2}{*}{ No } & \multirow{2}{*}{$\mathrm{CS}$} & \multicolumn{20}{|c|}{ Length of Observation (21) days } \\
\hline & & & 12 & 3 & 4 & 5 & 6 & 7 & 1 & 2 & 3 & 4 & 5 & 6 & 7 & 1 & 2 & 3 & 4 & 5 & 6 & 7 \\
\hline \multirow[b]{2}{*}{ Vaccinated } & 1 & - & $-\quad-$ & - & - & - & - & - & - & - & - & - & - & - & - & - & - & - & - & & - & - \\
\hline & 2 & - & $-\quad-$ & - & - & - & - & - & - & - & - & - & - & - & - & - & - & - & - & - & - & - \\
\hline \multirow[t]{2}{*}{ Control } & 3 & - & $-\quad-$ & - & - & - & - & - & - & - & - & - & - & - & - & - & - & - & - & - & - & - \\
\hline & ults & & $\begin{array}{l}\text { All } \\
\text { hem }\end{array}$ & & & & & & & & & & & & & & & & & & & \\
\hline \multicolumn{3}{|c|}{ Result Value } & Vace & nes & are & fe & l & & & & & & & & & & & & & & & \\
\hline
\end{tabular}




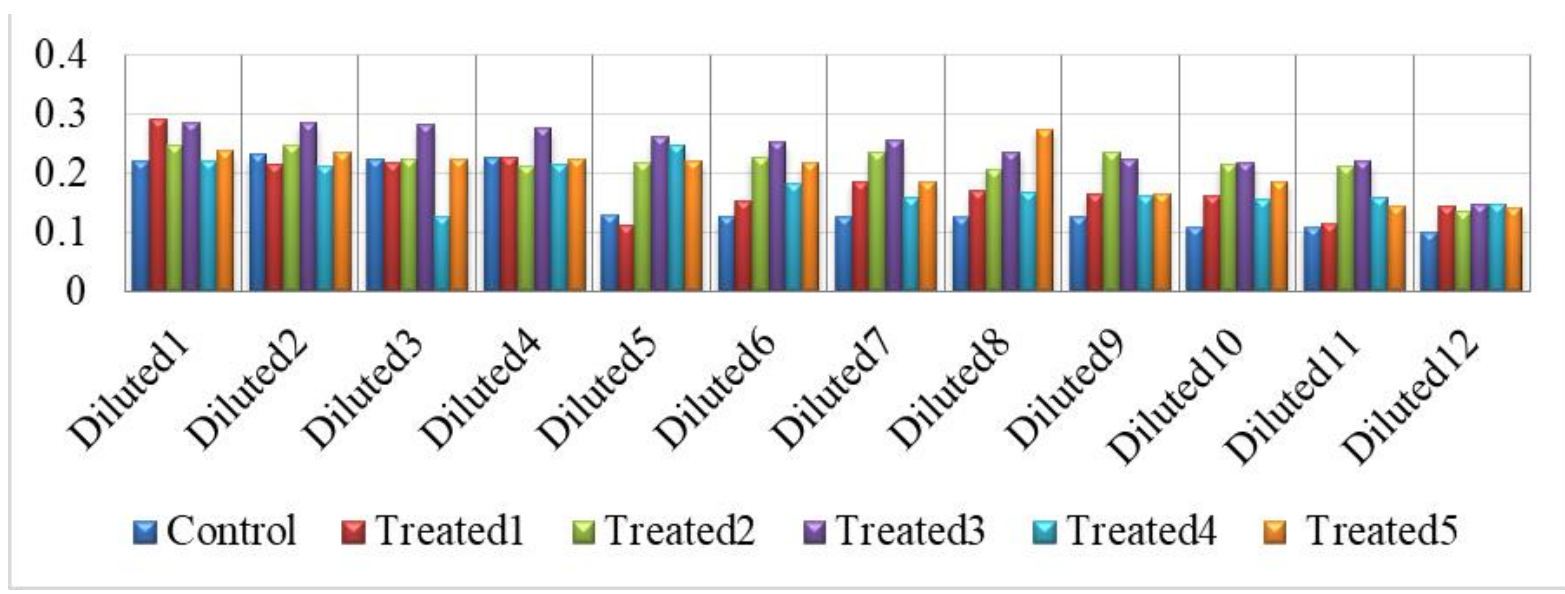

Figure 2. Swamp buffalo antibody titers before being immunized in various dilutions. $\mathrm{C}=$ negative control, $\mathrm{P}=$ Immunization treatments with cell-wall protein 100 ul, 1 - 5 $=$ Replication

\section{The Potency Test}

By the potency test show that all treated buffaloes live and does not show any clinical symptoms. The potency test was conducted by ELISA serological testing, this because ELISA serological testing can detect sensitively even for view protein antibody in serum and needed only small serum (Gazela, 1980). ELISA testing can detect until less than 0.0005 ug protein per-ml antibody (Tizard, 1988). Serum was taken from vena jugularis, and then it was tested its antibody production.

Antibody titres were determined by ELISA technic. Antibody was diluted from dari $2^{1}, 2^{2}, 2^{3}$ until $2^{12}$. Testing of antibody titres by ELISA is more sensitive and specific because the ELISA technic based on reaction of antigens (Ag) dan antibodies $(\mathrm{Ab})$. The antibody titres was determined at value of $\mathrm{OD} \chi 595 \mathrm{\eta m}$, in 3 time measurement (before immunization, $1^{\text {st }}, 2^{\text {nd }}$, and $3^{\text {rd }}$ of immunization).

The antibody titres of treated buffaloes before vaccinated (Ag of cellwall sel $P$. multocida) can be seen on Figure 2. The highest OD values are $0.292 ; 0.248 ; 0.286$; 0.248 ; and 0.274. Otherwise, OD values before immunization was less than 2 time
OD of negative control. This finding indicated that undeveloped yet of antibody against cell-wall of protein.

The antibody titre after $1^{\text {st }}$ immunization was taken in after treated buffaloes immunated by Ag (cellwall protein of Pasteurella multocida), as seen on Figure 3. The high OD values are $0.719 ; 0.748 ; 0.734 ; 0.728$ and 0.713 . Otherwise, OD valuesafter $1^{\text {st }}$ immunization was larger than 3 time OD negative control. This fainding indicate that $1^{\text {st }}$ immunization can stimulate antibody formation against the cellwall protein. The binding between $\mathrm{Ag}$ and $\mathrm{Ab}$ still can be detected obviously at diluted $2^{-1}$ until $2^{-6}$.

The antibody titre after $2^{\text {nd }}$ immunization was determined after treated buffaloes immunated with Ag (cell wall protein of $P$. multocida), as seen on Figure 4. The high OD values are $1.313 ; 1.453$; $1.576 ; 1,467$ and 1.361. Otherwise, OD value safter $2^{\text {nd }}$ immunization was larger than 6 time OD negative control. This fainding indicate that $2^{\text {nd }}$ immunization can stimulate antibody formation against the cellwall protein. This finding also confirmed the finding Tizard (1988) mentioned that vaccinated animal can produce more antibodies. 


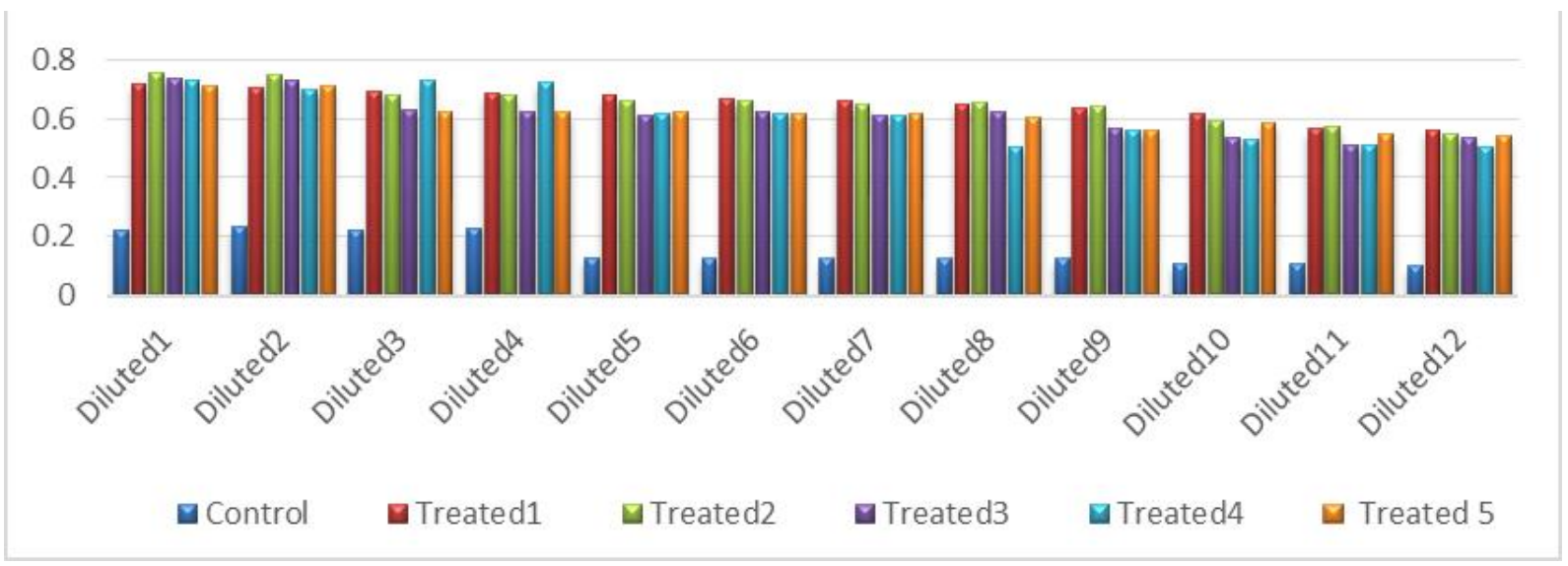

Figure 3. Swamp buffalo antibody titers after $1^{\text {st }}$ immunization in various dilutions.

Note: $\mathrm{C}=$ negative control, $\mathrm{P}=$ Immunization treatments with cell-wall protein $100 \mathrm{ul}, 1$ - 5 $=$ Replication

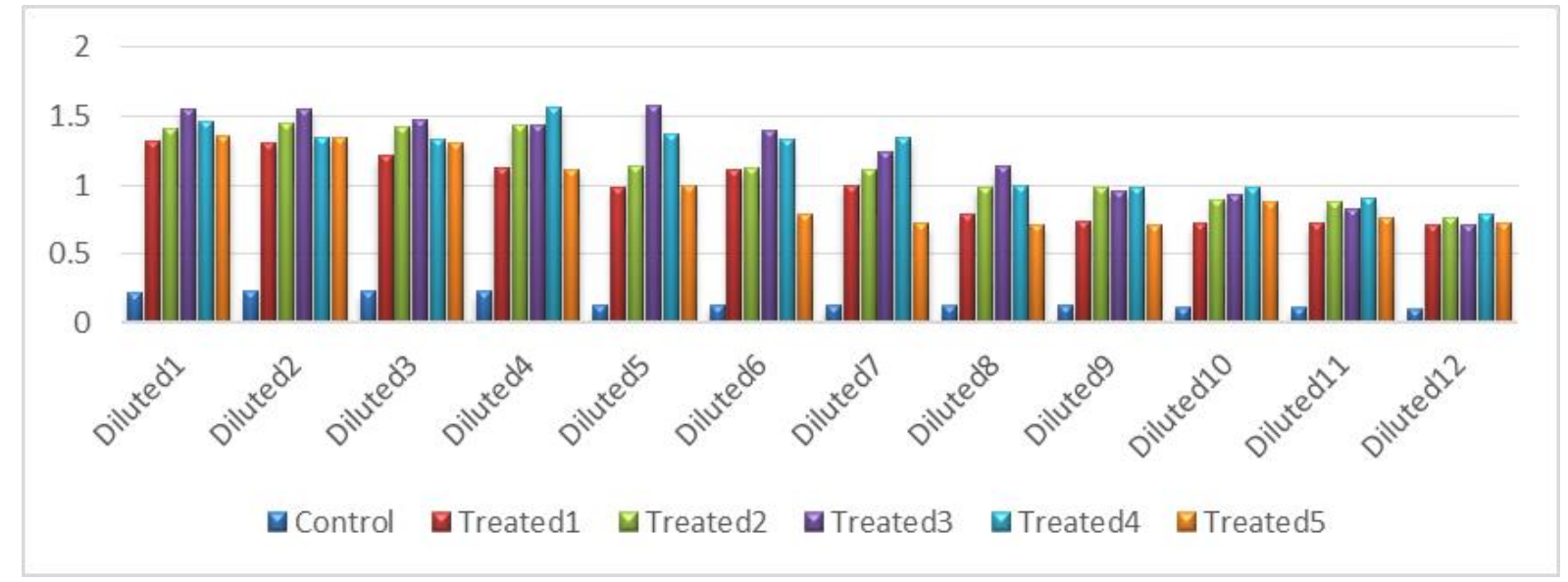

Figure 4. Swamp buffalo antibody titers after $2^{\text {nd }}$ immunization in various dilutions.

Note: $\mathrm{C}=$ negative control, $\mathrm{P}=$ Immunization treatments with cell-wall protein $100 \mathrm{ul}, 1-5$ $=$ Replication

The antibody titre after $3^{\text {rd }}$ immunization was determined after treated buffalo's immunated with $\mathrm{Ag}$ (cellwall protein of $P$. multocida), as seen on Figure 5. The high OD values are $1.821 ; 1.752 ; 1.775 ; 1.673$ and 1.741. Otherwise, OD value safter $3^{\text {nd }}$ immunization was 0.220 , larger than 7 time OD negative control. This fainding indicate that $3^{\text {nd }}$ immunization can stimulate antibody sharply formation against the cellwall protein.
Anova test of antibody titres show that treatments affect significantly on antibody titres $(\mathrm{p}<0.05)$, then further test was done by LSD. There are significant different among results of antibody titres, antibody 


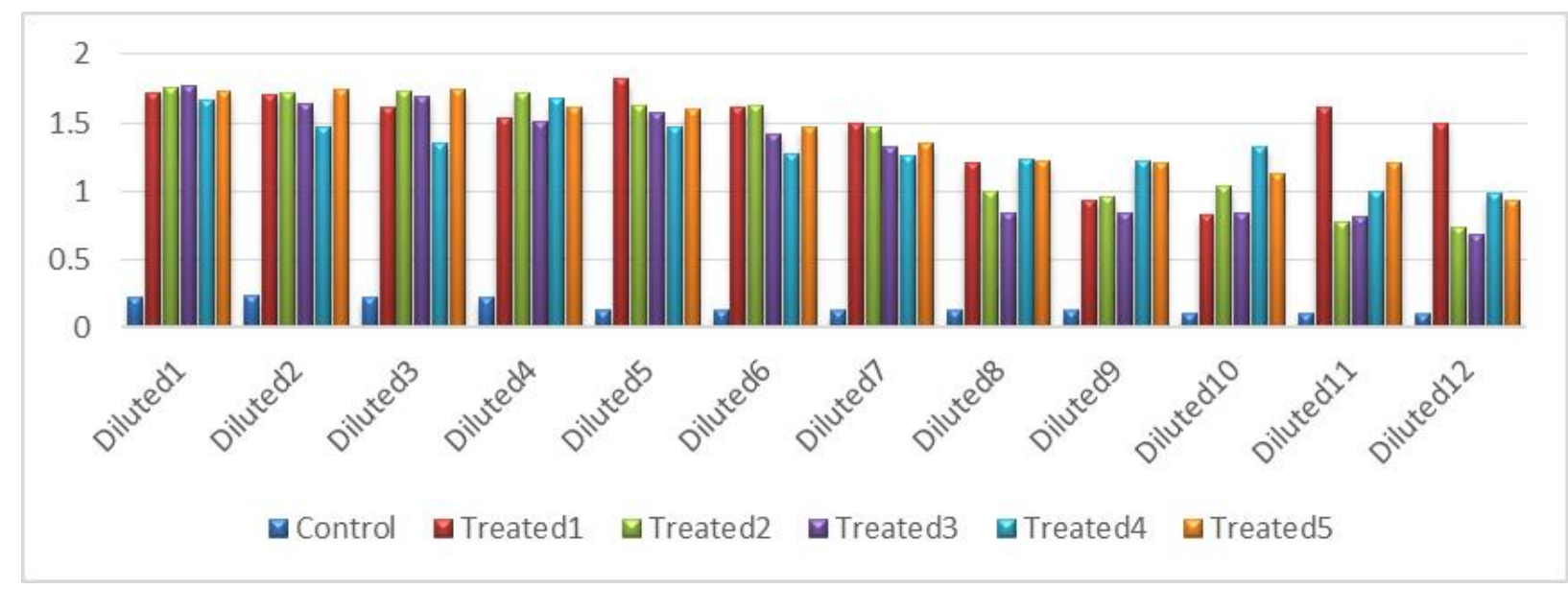

Figure 5. Swamp buffalo antibody titers after $3^{\text {rd }}$ immunization in various dilutions. $\mathrm{C}=$ negative control, $\mathrm{P}=$ Immunization treatments with cell-wall protein $100 \mathrm{ul}, 1-5=$ Replication

Table 4. The Antibody titers in buffalo after immunization

\begin{tabular}{|c|c|c|c|c|c|c|c|c|c|c|c|}
\hline \multirow[t]{2}{*}{$\begin{array}{l}\text { Immunazation } \\
\text { Time }\end{array}$} & \multicolumn{5}{|c|}{ Peak OD Values at } & \multirow{2}{*}{$\begin{array}{c}\text { Mean } \pm \\
\text { SD }\end{array}$} & \multicolumn{5}{|c|}{ Repeated Dilluted at } \\
\hline & 1 & 2 & 3 & 4 & 5 & & 1 & 2 & 3 & 4 & 5 \\
\hline $\begin{array}{l}\text { Before } \\
\text { Immunization }\end{array}$ & 0.292 & 0.248 & 0.286 & 0.24 & 0.724 & $0.268^{d} \pm 0.0230$ & $2^{-1}$ & $2^{-2}$ & $2^{-1}$ & $2^{-5}$ & $2^{-8}$ \\
\hline $1^{\text {st }}$ Immunization & 0.719 & 0.748 & 0.734 & 0.728 & 0.712 & $0.6846^{\mathrm{c}} \pm 0.0681$ & $2^{-1}$ & $2^{-2}$ & $2^{-1}$ & $2^{-1}$ & $2^{-1}$ \\
\hline $2^{\text {nd }}$ Immunization & 1.313 & 1.453 & 0.576 & 1.467 & 1.361 & $1.434^{\mathrm{b}} \pm 0.1020$ & $2^{-1}$ & $2^{-2}$ & $2^{-5}$ & $2^{-1}$ & $2^{-1}$ \\
\hline $3^{\text {rd }}$ Immunization & 1.821 & 1.752 & 1.775 & 1.675 & 1.741 & $1.7528^{\mathrm{a}} \pm 0.05$ & $2^{-5}$ & $2^{-1}$ & $2^{-1}$ & $2^{-4}$ & $2^{-2}$ \\
\hline
\end{tabular}

Hints : Numbers followed by different letters indicate there is significance at $5 \%$ tested with Anova and LSD

titre before immunization (0.2680) is significant different with antibody titres at immunization I (0.6846), II (1.4340) and immunization III (1.7528), as seen on Table 4.

The immunity system can differ between part of body system self and foreign thing entering the body. In general, the immunity system can divide into humoral immunity and seluler immnunity.

However, two mechanism of immunity can not separate one and another. The two systems can increase effectiveness each other, and interact to produce harmonic biological activities (Fenner dan Fransk, 1995).

Non-spesific immunity system is natural immunity system in the body but it has less protective system. All disease agents that

Journal of Wetlands Environmental Management

Vol 6, No 2 (2018) 93 - 111

http://dx.doi.org/10.20527/jwem.v6i2.165 entering into body will be destroyed this kind immunity because of non specific immunity of definite disease. In otherhand, specific immunity system consist of cell mediated immunity and antibody mediated immunity or well known as the humoral immunity system (Butcher dan Miles, 2003).

The humoral immunity sytem consist of antibody and fluid that are secreted from body organ. In otherhand, seluler immunity system is in form of macrophage, lymphosit, and neutrophil in cells. Antigens of cellwall protein $P$. multocida produce immun respons in the form of phagocytosis antigen by polimorphonuclear phagocyt cell or macrophage. If in the process of phagocytosis there are still antigens that are not yet phagocytic, then the antigen will 
stimulate a specific immune response to form antibodies.

Antibodies are produced by central lymphoid organs consisting of the bone marrow and thymus gland, especially by lymphocyte cells. There are two types of lymphocyte cells, namely B lymphocyte cells and T lymphocyte cells. These two cells work together to produce antibodies in the body. The antibodies and antigens have very specific relationships. This condition is seen when antigens enter the body. At that time, $\mathrm{T}$ lymphocyte cells immediately detect the characteristics and types of antigens. Then $\mathrm{T}$ lymphocytes react quickly by binding to the antigen through the surface of the receptor. After that, $\mathrm{T}$ lymphocyte cells divide and form clones. While the membrane surface produces monomeric immunoglobulin. Antigen molecules and antibody molecules bind to one another and the bonds of these molecules are placed on the macrophage. Sequentially, macrophages present antigens to B lymphocyte cells. Then, B-lymphocyte cells proliferate and become mature form, so that it can form antibodies againts to cellwall protein of $P$. multocida by cell B (Austyn dan Wood, 1994; Bellanti, 1993).

Increased antibody titers after immunization I, II, and III showed an immune response to antigens of the cell wall protein of P. multocida. Immunization with the same antigen increases higher antibody titer. This is supported by results of Goldsby et al. (2000) and Herscowitz (1993), after the onset of antibodies, biosynthesis of active antibodies begin, so that there is an increase in antibody concentration logarithmically, reached the highest antibody titer after 812 days. According to Austyn and Wood (1994), Goldsby et al. (2000), and Herscowitz (1993), the second exposure to the same immunogen will cause the addition of immune response in the form of imonocompetent cells and accelerated antibodies. In the secondary response, the latent period is shorter, the antibody synthesis rate is faster, the antibody titer peak lasts longer, the antibody power is higher, there are more memory cells and more IgG.

\section{CONCLUSION}

Based on the results of observations in the laboratory and the field, safety test or potential test for the vaccines of Pasteurella multocida cell-wall protein can be used to prevent hemorrhagic septicemia that attacks swamp buffaloes, both laboratory scale and field scale.

\section{RECOMENDATION}

Further research is needed to test potential in other areas, so that the vaccine obtained can be used for field testing (in vivo).

\section{AKNOWLEDGMENT}

This research is the result of research of Hibah Unggulan Perguruan Tinggi (PUPT) in 2016-2017, with contract numbers 244 / UN8: 2 / PL / 2016. The author would like to thank the Lab chairman and technician of Genetical Engineering. Faculty of Science and Technology, Airlangga University, Kepala Desa Tampangkang and Kepala Desa Bati-Bati and their livestock groups.

\section{REFERENCES}

Austyn, J.N. and K.J. Wood. 1994. Principle of Cellular and Molecular Immunology. Oxford: Oxford University Press.

Bellanti. J.A. 1993. Immunologi 111. Terjemahan A. S. Wahab. Yogyakarta: Gadjah Mada University Press.

Butcher, G.D, and R.D. Miles. 2003. The Avian Immune System. Edis.ifas.ufl.edu. (28 September 2014).

Cappucino, J.G. and N. Sherman. 2001. Microbiology. A Laboratory Manual. Sixth Edition. Rockland Community College. New York. 491p. 
Carter, G.R. and M.C.L. De Alawis. 1989. Haemorrhagic Septicaemia. In: Adlam, C. and Rutter J.M., Pasteurella and Pasteurellosis. Academic Press Limited, London. p. $131-160$.

Carter, G. R., A. Myint., R. Van Khar, and A. Khin. 1991. Immunisation of ca and buffaloes with live haemorrha 41 septicaemia vaccine. Vet. Rec. 129: 203.

De Alwis, M.C.L. and A.A. Vipulasiri. 1980. An epizootiological study of Haemorrhagic Septicaemia in Srilanka. Ceylon Vet. J. 28: 24 - 35.

De Alwis, M.C.L. 1981. Mortality among cattle and buffaloes in Srilanka due to haemorrhagic septicaemia. Trop. Anim. Health. Prod. 13: 195 - 202.

De Alwis, M.C.L. 1992. Haemorrhagic Septicaemia. A General Review. Brit. Vet. J.148: 99 - 112.

De Boer, S.H., dan Schaad, N, 1990. Preparation of antigen bakterial. dalam Serological mathods for detiction and identification of viral and bacterial plant pathogen. R. Hapton, E. Ball and S. De Boer (Eds); 27-31.

Diallo IS, Frost AJ. 2000. Survival of avian strains of Pasteurella multocida in chicken serum. Veterinary microbiology 72(1):153-161.

Eriksen L, Aalbaek B, Leifsson PS, Basse A, Christiansen T, Eriksen E. 1999. Hemorrhagic septicemia in fallow deer (Dama dama) caused by Pasteurella multocida. Zoo and Wildlife Medicine 30(2):285-292.

Fenner J, Fransk. 1995. Virologi Veteriner. Edisi ke-2. Harya P, Penerjemah. Semarang: IKIP Semarang Press

Gazela. Z. and R. A. Bankowski. 1980. Comparison of Tissue Culture Virus Neutralization Test and the Enzyme Linked Immuno Sorbent Assay for Measurement Antibodies to Infectious Bronchitis. Avian Dis. Vol. 25 : 121

Goldsby, R.A., T.J. Kindt, dan B.A. Osborne. 2000. Kuby Immunology, edisi 4. W.H. Freeman and Company, New York

Journal of Wetlands Environmental Management

Vol 6, No 2 (2018) 93 - 111

http://dx.doi.org/10.20527/jwem.v6i2.165
Griffin D, Chengappa M, Kuszak J, McVey DS. 2010. Bacterial pathogens of the bovine respiratory disease complex. Veterinary Clinics of North America: Food Animal Practice 26(2):381-394.

Gyles C.L., J.F. Prescott, J.G. Songer, C.O. Thoen. 2011.Pathogenesis of bacterial infections in animals.John Wiley \& Sons.

Hercowitz, H.B. 1993. Immunofisiologi: Fungsi Sel dan interaksi Seluler dalam Pembentukan Antibodi. Dalam Belanti, J.A. (Eds) Immunologi 111. Terjemahan A. S. Wahab. Yogyakarta: Gadjah Mada University Press.

Herliani dan Abrani S. 2010. Pengembangan vaksin protein pili untuk pengendalian penyakit kolera ( $P$. multocida) pada itik alabio. Ziraa'ah Vol. 29 Nomor 3, Oktober 2010 ISSN. 1412-1468. Hal. 13-15

Herliani dan Abrani S. 2011. Karakterisasi protein dinding sel Pasteurella multocida isolat lokal. Agroscientiae Vol. 18 Nomor 3 Desember 2011 ISSN 0854-2333. Hal 144-149

Kubatzky KF. 2012. Pasteurella multocida and immune cells. Curr Top Microbiol Immunol 361:53-72. doi:10.1007/82_2012_204

Mosier, D. 1993. Prevention and control of Pasteurellosis. 121-134. in: ACIAR Proceedings no. 43: Pasteurellosis in Production Animals. B.E. PATTEN et al., (Eds).

Natalia L, Priadi A. 2006. Penyakit Septicaemia Epizootica: penelitian penyakit dan usaha pengendaliannya pada sapi dan kerbau di indonesia. Lokakarya Nasional Ketersediaan IPTEK dalam Pengendalian Penyakit Stategis pada Ternak Ruminansia Besar. Perpustakaan digital Badan Litbang Pertanian. 14.

Priadi, A. and L. Natalia. 2002. Proteksi Vaksin Hidup Pasteurella multocida B:3,4 terhadap Penyakit Septicaemia epizootica pada Sapi. JITV 7(1): 55-61.

Ramdani. 1997. Pengembangan vaksin SE dari isolat lokal untuk pencegahan 
penyakit ngorok pada sapi dan kerbau. Pros. simposium sehari penyakit ngorok (Septicaemia epizootica, SE). Bogor 19 Agustus 1997. Balitvet, Bogor. hlm. 44 -46 .

Syamsudin, A. 1993. Control of haemorrhagic septicaemia in Indonesia A short history. In: ACIAR Proceedings no. 43: Pasteurellosis in Production Animals. B.E. PATTEN et al., (Eds). 180-181.

Supar, Y.S., Djaenuri, N. Kurniasih, B. Purwadikarta dan Sjafei, 2000. Pengembangan vaksin kolera unggas II: Patogenitas Pasteurella multicida isolat lokal pada itik dan proteksinya dengan vaksinasi. JITV 6 (2): 120-125.

Supar, Y.S., Djaenuri, N. Kurniasih, B. Poerwadikatra dan Sjafei. 2001a. Pengembangan vaksin kholera unggas: I. Proteksi vaksin Pasteurella multocida isolat lokal pada ayam terhadap uji tantang dengan galur homolog dan heterolog. JITV 6: 59-67.

Supar, Y. S., Djaenuri, N. Kurniasih, B. Poerwadikatra dan Sjafei. 2001b.
Pengembangan vaksin kholera unggas: II. Pantogenitas dan proteksi vaksin Pasteurella multocida isolat lokal pada itik percobaan. JITV 6: 120-125.

Supar, Y. dan T. Ariyanti, 2007 Karakterisasi molekuler Pasteurella multocida Kaitannya Dengan Epidemiologi dan Pengembangan Vaksin Isolat Lokal Wartazoa 17 (4) 147-155.

Tizard, I. A. dalam Partadireja, M. 1988. Pengantar Immunologi Veteriner. Edisi 2. Airlangga Univ. Press. Surabaya. Indonesia

Woodcock, J.B. 1992. The Biology of Pasteurella moltocida and Pasteurella haemolytica. In Pasteurellosis in Production animals. $25 \quad-34$ An Internasional Worksshop for Pasteurellosis, ACIAR, Bali, Indonesia.

Wilkie I.W., M. Harper, J.D. Boyce, B. Adler B. 2012. Pasteurella multocida: diseases and pathogenesis. Curr Top Microbiol Immunol 361:1-22. doi:10.1007/82_2012_216 